\title{
Nimbecidine induced gene mutations in internal transcribed spacers 1 and 2 of Anopheles stephensi
}

\author{
Preety B hinder*, A sha C haudhry and A diti Soni \\ Department of Zoology, Panjab University, Chandigarh-160014, INDIA \\ *Corresponding author. E-mail: preety.bhinder@yahoo.com
}

\begin{abstract}
The genotoxic effects of nimbecidine, a commercial botanical pesticide derived from the neem tree were assessed by PCR assay on a mosquito Anopheles stephensi taken as an experimental model. After treatment with $\mathrm{LC}_{20}$ of the nimbecidine, the sequence variations in the internal transcribed spacers 1 and 2 (ITS1 and ITS2) of control and treated individuals were studied from their sequence alignment data and the mutations in the form of insertions, deletions, and substitutions were analyzed. Nimbecidine treatment induced 16 deletions, 13 insertions, 93 transitions and 140 transversions in the ITS1 sequence. Similarly, in the ITS2 sequence of treated individual there were 2 deletions, 4 insertions, 15 transitions and 39 transversions. Present study suggests that plant based pesticides also effect the integrity of normal DNA sequences.
\end{abstract}

Keywords: Anopheles stephensi, Nimbecidine genotoxicity, ITS1 and 2

\section{INTRODUCTION}

As an alternative to synthetic pesticides, nowadays chemical derivatives isolated from neem seed extract are currently being used in agriculture (Anon, 1992; Liang et al., 2003; Saber et al., 2004; Shoaib et al., 2010). Nimbecidine is one such commercial compound in which azadirachtin is the principal active ingredient. Azadirachtin, a steroid akin to tetranortriterpenoid (limonoid), is the most active principle component present in the extract of neem (Singh et al., 1993). The products of neem in the form of different formulations are being extensively used for their supposedly non-pollutant and environment friendly nature and are also being used for the treatment of a number of diseases in man (Van Der Nat et al., 1991). However, some of these neem derivatives have been experimentally shown to induce chromosomal aberrations in the bone marrow cells of rats (Awasthy et al., 1995, 1999). Rojanapo and Tepsuwan (1992) also reported a certain level of mutagenicity of flower extract of neem in TA 98 strain of Sal monella typhi murium. As a contraceptive, various neem formulations were found to adversely affect the reproductive performance in males (Sinha et al., 1984; Upadhyay and Talwar, 1993) clearly depicting the biological hazards of the neem products. In the recent years large scale use of nimbecidine in agricultural practices, the exposure of human population in general and the vulnerable groups such as virgin or pregnant women in particular has become a subject of concern (Srivastava and Raizada, 2007). Apart from a number of physiological complications expected from such formulations, the assessment of genotoxic potential of nimbecidine at various levels of its action on the genetic material has become crucial. In reference to this, the present study was carried out to evaluate the mutational index of this pesticide at the molecular level of nuclear DNA. For this, internal transcribed spacers 1 and 2 (ITS1 and ITS2) were PCR amplified to study the incidence of induced point mutations in a mosquito, Anopheles stephensi taken as an experimental model.

\section{MATERIALS AND METHODS}

Anopheles stephensi Liston, taken as an experimental insect for the present set of investigations was procured from the cattle sheds in the early morning collections from the village inhabitations near Chandigarh. The gravid females were held in the test tubes where they were allowed to oviposit on a strip of wet filter paper. The eggs procured in this way were allowed to grow through all the larval stages on a protein rich diet of finely powdered dog biscuits and yeast tablets (Singh et al., 1975; Rao, 1984; Clements, 1996). Freshly hatched unfed adults were stored in eppendorf tubes at $-20^{\circ} \mathrm{C}$ and the dried samples were individually homogenized for DNA extraction. Nimbecidine, used in the present experiments, is a commercial botanical pesticide derived from the seed kernels of neem plant. The extract contains azadirachtin which is the principal constituent of this chemical. Nimbecidine is commercially available as a white liquid with a strong smell. Its technical specifications are: CAS No. 11141-17-6, chemical formula $\mathrm{C}_{35} \mathrm{H}_{44} \mathrm{O}_{16}$ and molecular weight 720.71 . In the experimental studies aimed at the evaluation of genotoxicity of any such chemical formulation it is important to determine a suitable dose 
for its effective action in the test system. Therefore, for the present motive of research $\mathrm{LC}_{20}$ was found to be an ideal concentration in water, which was standardized by probit analysis (Finney, 1971). The second instar larvae of An. stephensi were treated by rearing them in water having $4.6 \times 10^{-2} \mu \mathrm{l}$ of nimbecidine for $24 \mathrm{~h}$ after which they were transferred to chemical free distilled water in order to complete their metamorphosis upto the stage of adult. The treated and parallel controls were maintained in a BOD incubator. The extraction of DNA, its integrity testing and amplification of ITS1 and 2 were carried out as per the standard protocols of Sambrook et al. (1989), Williams et al. (1990) and Ausubel et al. (1999), respectively. The specific forward and reverse primers: 5'-CCTTTGTACACACCGCCCGT-3' and 5'GTTCATGTGTCCTGCAGTTCAC-3' for ITS 1 and 5'TGTGAACTGCAGGACACAT- 3 , and 5'TATGCTTAAATTCAGGGGGT-3' for ITS2 were used for amplifying both the sequences of control and treated stocks of An. stephensi and the PCR end products were electrophoesed through $2 \%$ agarose gel stained with ethidium bromide. The DNA bands generated in this way were visualized over UV Transilluminator and photographed using Polaroid camera. A 100 base pair DNA ladder was also run along with the amplification products for calculating the number of base pairs in each band. The amplified products were sequenced by outsourcing the DNA samples to Chromus Biotech Pvt.

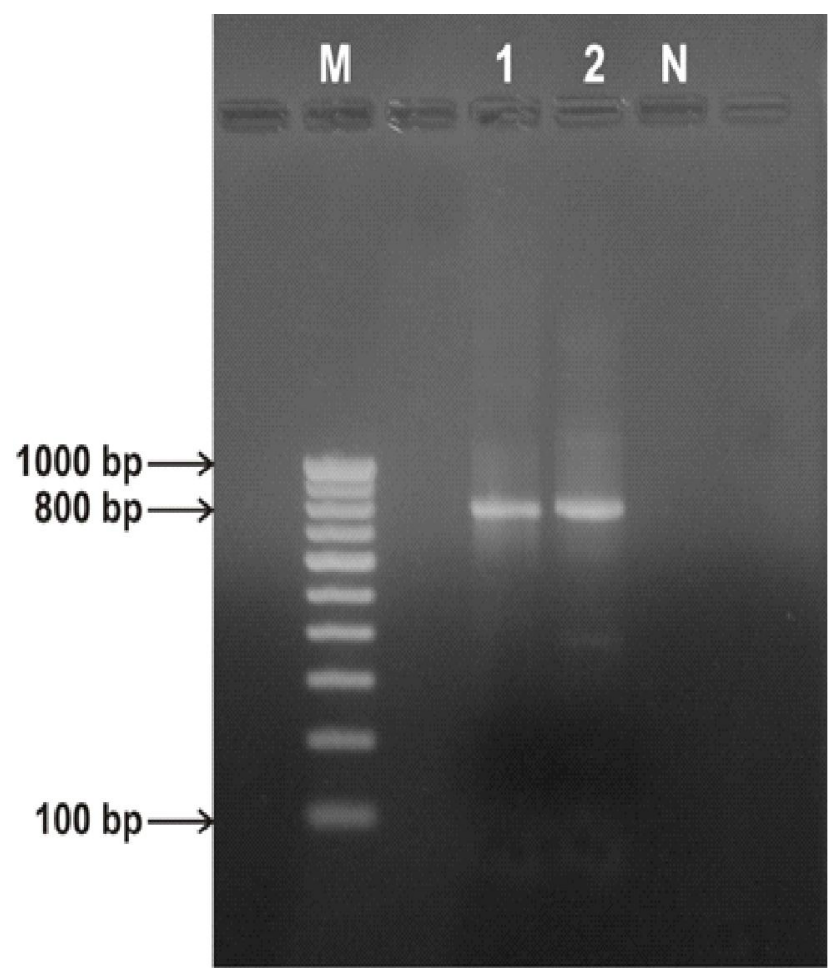

Fig. 1. PCR generated DNA bands from ITS1 of nontreated and treated An. stephensi. Lane M-DNA ladder, lane 1-band gener ated from nontreated individual, lane 2- band generated from treated individual, lane $\mathrm{N}$ - negative control.
Ltd., Bangalore and the data so obtained were aligned and analyzed using ClustalW software.

\section{RESULTS AND DISCUSSION}

The PCR amplification of ITS1 region of An. stephensi generated a single prominent band of approximately 800 bp length from the non-treated controls and nimbecidine treated individuals while a band of approximately $400 \mathrm{bp}$ was generated from ITS2. In Fig. 1, lane $\mathrm{M}$ shows the standard DNA gene ruler while lanes 1 and 2 contain the amplified products from ITS1 of control and nimbecidine treated samples respectively and lane $\mathrm{N}$ represents the negative control. Similarly, in figure 2, lane $\mathrm{M}$ shows the standard DNA gene ruler while lanes 1 and 2 contain the amplified products from ITS2 of control and nimbecidine treated samples respectively and lane $\mathrm{N}$ represents the negative control. In the sequence alignment of control and treated individuals of An. stephensi (Figs. 3, 4) the loci marked with asterisk $(*)$ are the regions where bases are identical in both type of individuals while dashes (-) indicate the loci differing due to insertion or deletion of bases. Those regions which are not indicated by either asterisk or dash are the loci effected by substitution i.e. transitions and transversions. Measurable differences indicative of genetic damage due to nimbecidine were observed when control and treated sequences were compared. It was found that nimbecidine treated ITS 1 sequence had 16 deletions, 13 insertions, 93 transitions

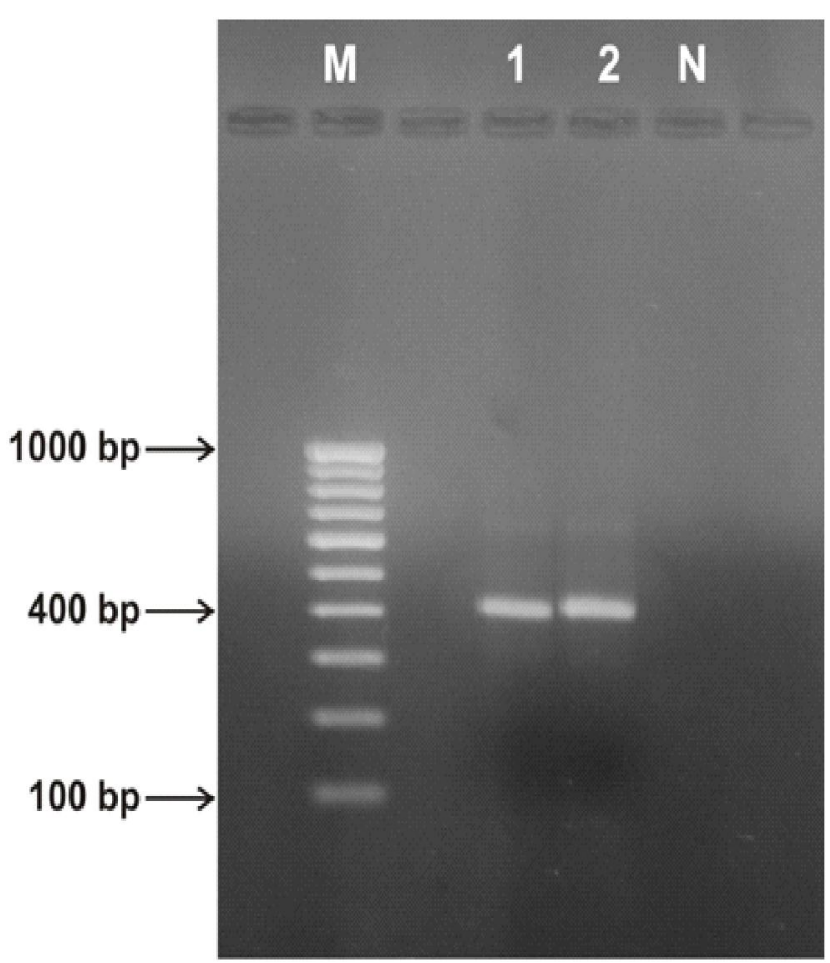

Fig. 2. PCR generated DNA bands from ITS2 of nontreated and treated An. stephensi. Lane M-D NA ladder, lane 1-band gener ated from nontreated individual, lane 2- band generated from treated individual, lane $\mathrm{N}$ - negative control. 


\begin{tabular}{|c|c|c|}
\hline Control & CCTTTGTTCCCCGCCTGTCTATTGTACGTCCTGCCGGTGAACTAGTCGACTACTCCTCCT & 60 \\
\hline Treated & 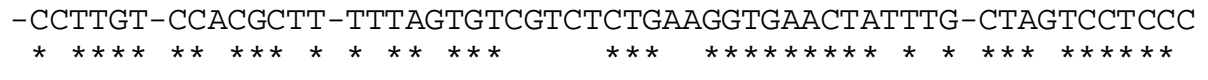 & 56 \\
\hline $\begin{array}{l}\text { Control } \\
\text { Treated }\end{array}$ & 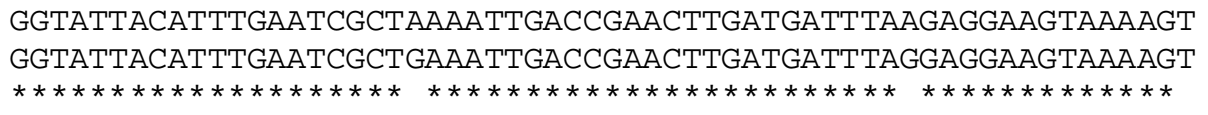 & $\begin{array}{l}120 \\
116\end{array}$ \\
\hline $\begin{array}{l}\text { Control } \\
\text { Treated }\end{array}$ & 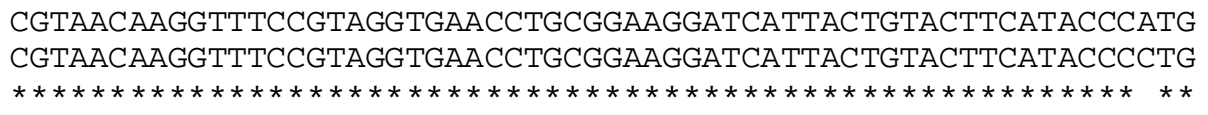 & $\begin{array}{l}180 \\
176\end{array}$ \\
\hline $\begin{array}{l}\text { Control } \\
\text { Treated }\end{array}$ & $\begin{array}{l}\text { GAGCGCATAAATGAA--CAACACCCCCCGCAATGTGCCAGCGTGCGCGCCCGAGTCTCCT } \\
\text { GGGCGCATAAATGAAAACAACCCCCCCAGTTGCGTACCCGTGTGCGCGCCCGACTCATCG } \\
\star \star \star \star \star \star \star \star \star \star \star \star \star ~\end{array}$ & 238 \\
\hline $\begin{array}{l}\text { Control } \\
\text { Treated }\end{array}$ & 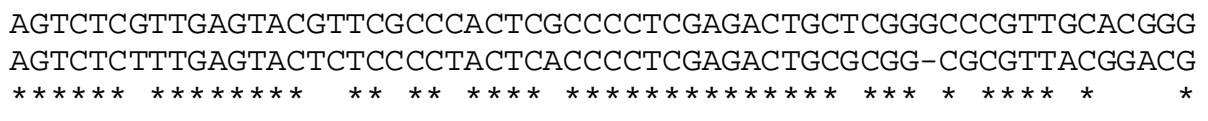 & $\begin{array}{l}298 \\
295\end{array}$ \\
\hline $\begin{array}{l}\text { Control } \\
\text { Treated }\end{array}$ & 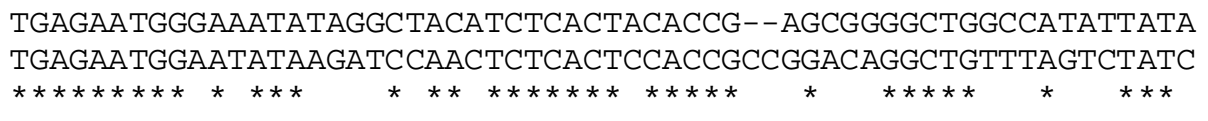 & $\begin{array}{l}356 \\
355\end{array}$ \\
\hline $\begin{array}{l}\text { Control } \\
\text { Treated }\end{array}$ & 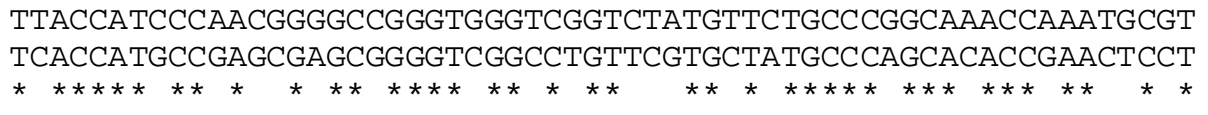 & $\begin{array}{l}416 \\
415\end{array}$ \\
\hline $\begin{array}{l}\text { Control } \\
\text { Treated }\end{array}$ & 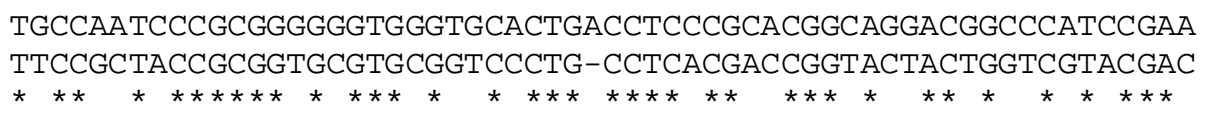 & $\begin{array}{l}476 \\
474\end{array}$ \\
\hline $\begin{array}{l}\text { Control } \\
\text { Treated }\end{array}$ & 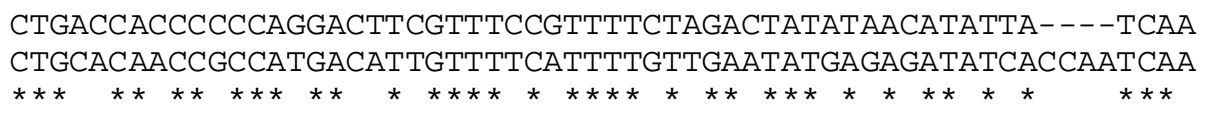 & $\begin{array}{l}532 \\
534\end{array}$ \\
\hline $\begin{array}{l}\text { Control } \\
\text { Treated }\end{array}$ & 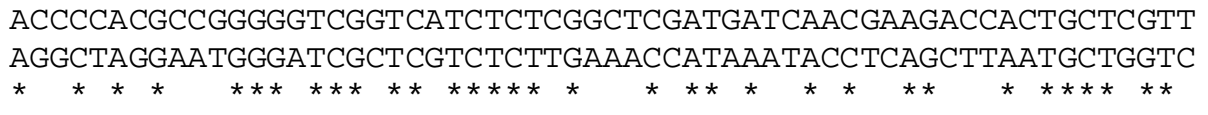 & $\begin{array}{l}592 \\
594\end{array}$ \\
\hline $\begin{array}{l}\text { Control } \\
\text { Treated }\end{array}$ & 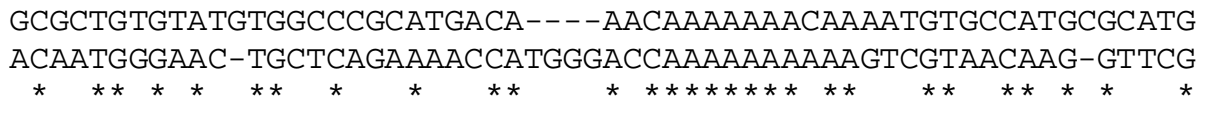 & $\begin{array}{l}648 \\
652\end{array}$ \\
\hline $\begin{array}{l}\text { Control } \\
\text { Treated }\end{array}$ & 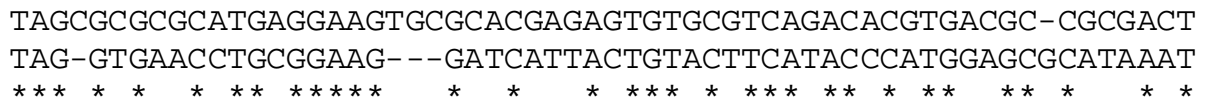 & $\begin{array}{l}707 \\
708\end{array}$ \\
\hline $\begin{array}{l}\text { Control } \\
\text { Treated }\end{array}$ & 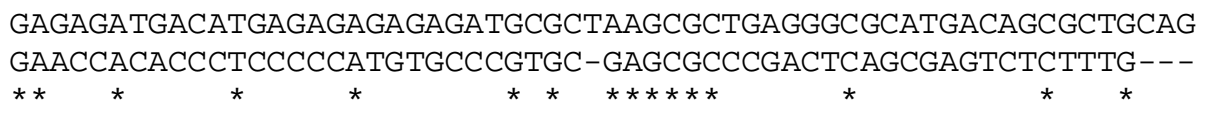 & $\begin{array}{l}767 \\
764\end{array}$ \\
\hline
\end{tabular}

Fig. 3. Sequence alignment of ITS1 sequences of control and treated An. stephensi. (*identical bases, - inserted/ deleted bases).

and as many as 140 transversions. Similarly, in nimbecidine treated ITS2 sequence there were only 2 deletions, 4 insertions, 15 transitions and 39 transversions (Tables 1-5).

The present results have clearly demonstrated gene mutations in An. stephensi DNA. Most of the toxic chemicals which produce genotoxic effects have been known to form reactive oxygen species as well as electrophilic free-radical metabolites that interact with
DNA to cause disruptive changes in the form of breaks and other related damage in the double helical organization of nucleotides (Klopman et al., 1985). Azadirachtin, which is a principle component of nimbecidine, has been reported to have a mitotic poisoning effect on mouse chromosomes (Awasthy et al., 1995; Awasthy, 2001) while its enzymatic biotransformation has been suspected to produce metabolites and oxygen free radicals (Sies, 1993). These 
Table 1. Deletions and insertions in ITS1 of nimbecidine treated An. stephensi.

\begin{tabular}{|c|c|c|c|c|}
\hline Type of mutation & $\begin{array}{c}\text { Total number of } \\
\text { mutations }\end{array}$ & Bases involved & Number of base/s & Type of base/s \\
\hline \multirow[t]{12}{*}{ Deletion } & 16 & 1 & 1 & $\mathrm{C}$ \\
\hline & & 8 & 1 & $\mathrm{~T}$ \\
\hline & & 17 & 1 & G \\
\hline & & 49 & 1 & A \\
\hline & & 285 & 1 & G \\
\hline & & 446 & 1 & A \\
\hline & & 604 & 1 & G \\
\hline & & 643 & 1 & $\mathrm{C}$ \\
\hline & & 652 & 1 & $\mathrm{C}$ \\
\hline & & $668-670$ & 3 & $\mathrm{~T}, \mathrm{G}, \mathrm{C}$ \\
\hline & & 737 & 1 & $\mathrm{~T}$ \\
\hline & & $765-767$ & 3 & $\mathrm{C}, \mathrm{A}, \mathrm{G}$ \\
\hline \multirow[t]{5}{*}{ Insertion } & 13 & 195-196 & 2 & $\mathrm{~A}, \mathrm{~A}$ \\
\hline & & $335-336$ & 2 & $\mathrm{C}, \mathrm{C}$ \\
\hline & & $528-529$ & 4 & $\mathrm{C}, \mathrm{C}, \mathrm{A}, \mathrm{A}$ \\
\hline & & $618-619$ & 4 & $\mathrm{~T}, \mathrm{G}, \mathrm{G}, \mathrm{G}$ \\
\hline & & 700-701 & 1 & G \\
\hline
\end{tabular}

Control

Treated

Control

Treated

Control

Treated

Control

Treated

Control

Treated

Control

Treated

Control

Treated
CCTTGTCACCGCCCGTCCATTGTACCCTCTGCCGGCCTTGTTACTACTCCC-CTGGATTA 59 -TTCGTAGCCGCCCGTCCTTTGTACAATG-GCCGTGTTGTAGACTACTCCCGCTCCTATG 58



CTAGTTTGAATCGCTAACATTGACCGAACTTGATGATTTAGAG---GAAGTAAAAGTCGT 116 CACTATTGCATCGTTAACATTGTACGAACTTGATGATTATAAGAGAGAAGTAAAAGTCGT 118



AACAAGGTTTCCGTAGGTGAACCTGCGGAAGGATCATTACTGTACTTCATACCCATGGAG 176 AACAAGGTTTCCGTAGGTGAACCTGCGGAAGGATCATTACTGTACTTCATACCCATGGAG 178

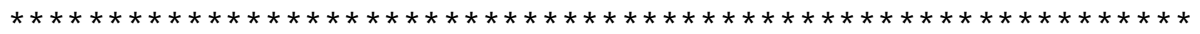

CGCATAAATGAACCACACCCCCCCCCATGTGCCCGTGCGCGCGCCCGACTCAGCGAGTCT 236 CGCATAAATGAACCACACCCTCCCCCATGTGCCCGTGCGAGCGCCCGACTCAGCGAGTCT 238

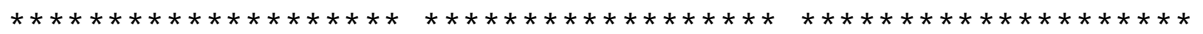

CTTTGAGTACTTTCCCCTACTCACCCCTCGAGACTGCCCGGGGGCATTGCACACGTGAGA 296 CTTTGAGTACTTTCCCCTACTCACCCCTCGAGACTGCGCGGGGTCATTGGACACGTGAGA 298

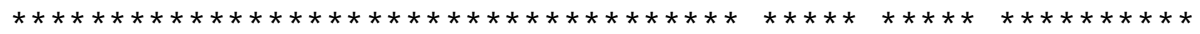

ATGGTATAGCTTCGAGAAATCTCCCTCCAGCTGCCAACTCGATGTTCAGTCTCCATCCCA 356 GTGGTCTAGCTTCGAGAAATCTACCTCCAGCTGGCCAGTCGATGTTCAGTTTCTATCGGA 358



ATGCCGACCGAGGGCTGGCCGTATGTCCGGCCTATGTCCCGCGCACCACTCCCATTTGCG 416 GTGCCGACGGAGGGCTGGCCGTATGTCCGGCCTACGTAACGCGTTGCACTCCCATTTGTG 418

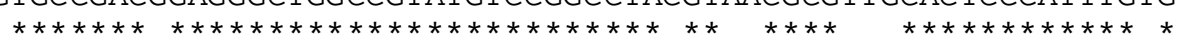

Fig. 4. Sequence alignment of ITS2 sequences of control and treated An. stephensi. (*identical bases, - inserted/ deleted bases).

effects were considered similar to other xenobiotics, including damage to spindle apparatus and unequal distribution of the chromosomes during anaphase, leading to mitotic breakdown. In relevance to the structure based toxicity of azadirachtin, Rosenkranz and Klopman (1995) identified the presence of atleast five copies of biophores in azadirachtin, which were considered as potent carcinogens. Akudugu et al. (2001) evaluated the cytotoxicity of azadirachtin in human glioblastoma cell line in which they found considerable reduction in the percentage of dividing cells, formation of micronuclei and decreased cell survival. While studying the sperm head assay, Khan and Awasthy (2003) observed that azadirachtin extract induced structural and numerical changes in the spermatocyte chromosomes as well as synaptic disturbances at the first metaphase with 
Table 2. Substitutions in ITS1 of nimbecidine treated An. stephensi.

\begin{tabular}{|c|c|c|c|c|}
\hline $\begin{array}{l}\text { Type of } \\
\text { substitution }\end{array}$ & $\begin{array}{l}\text { Total number of } \\
\text { substitutions }\end{array}$ & $\begin{array}{l}\text { Type of bases } \\
\text { substituted }\end{array}$ & $\begin{array}{l}\text { Total number of bases } \\
\text { substituted }\end{array}$ & Position of bases in the sequence \\
\hline \multirow[t]{4}{*}{ Transition } & \multirow[t]{4}{*}{93} & $\mathrm{~A} \rightarrow \mathrm{G}$ & 22 & $\begin{array}{c}81,106,182,210,294,315,336 \\
367,400,419,421,470,518,520 \\
554,632,697,727,729,738,756, \\
758\end{array}$ \\
\hline & & $\mathrm{G} \rightarrow \mathrm{A}$ & 26 & $\begin{array}{c}214,265,292,296,308,316,340, \\
372,411,504,547,562,569,593, \\
595,615,637,657,675,683,694 \\
702,704,710,715,749\end{array}$ \\
\hline & & $\mathrm{T} \rightarrow \mathrm{C}$ & 20 & $\begin{array}{c}3,29,60,211,255,319,352,358 \\
383,389,403,412,527,592,603 \\
634,647,714,732,744\end{array}$ \\
\hline & & $\mathrm{C} \rightarrow \mathrm{T}$ & 25 & $\begin{array}{c}15,30,47,208,219,236,261,347 \\
348,388,459,468,497,502,537 \\
560,572,581,582,608,645,654 \\
703,734,765\end{array}$ \\
\hline \multirow[t]{8}{*}{ Transversion } & \multirow[t]{8}{*}{140} & $\mathrm{~A} \rightarrow \mathrm{T}$ & 9 & $\begin{array}{c}209,310,351,511,633,646,673 \\
676,766\end{array}$ \\
\hline & & $\mathrm{T} \rightarrow \mathrm{A}$ & 9 & $\begin{array}{c}235,314,495,519,564,571,601, \\
614,641\end{array}$ \\
\hline & & $\mathrm{A} \rightarrow \mathrm{C}$ & 26 & $\begin{array}{c}26,178,200,217,322,330,356 \\
422,442,455,476,480,574,577 \\
580,616,620,659,662,692,711 \\
716,718,721,723,731\end{array}$ \\
\hline & & $\mathrm{C} \rightarrow \mathrm{A}$ & 29 & $\begin{array}{c}11,34,35,206,321,338,405,424 \\
451,454,471,481,484,514,541 \\
542,562,563,584,596,610,612 \\
629,638,656,672,698,706,757\end{array}$ \\
\hline & & $\mathrm{G} \rightarrow \mathrm{T}$ & 24 & $\begin{array}{c}28,45,245,254,317,346,385,413 \\
418,431,440,462,465,491,543 \\
576,677,685,689,726,728,751 \\
759,761\end{array}$ \\
\hline & & $\mathrm{T} \rightarrow \mathrm{G}$ & 7 & $22,238,281,350,439,589,754$ \\
\hline & & $\mathrm{G} \rightarrow \mathrm{C}$ & 21 & $\begin{array}{l}232,258,297,339,370,380,415 \\
433,437,461,551,566,607,679 \\
712,720,722,724,730,745,755\end{array}$ \\
\hline & & $\mathrm{C} \rightarrow \mathrm{G}$ & 15 & $\begin{array}{c}27,53,287,295,364,369,375,467 \\
487,509,522,534,535,539,589\end{array}$ \\
\hline
\end{tabular}

Table 3. Deletions and insertions in ITS2 of nimbecidine treated An. stephensi.

\begin{tabular}{lcccc}
\hline Type of mutation & $\begin{array}{c}\text { Total number of } \\
\text { mutations }\end{array}$ & Bases involved & Number of base/s & Type of base/s \\
\hline Deletion & 2 & 1 & 1 & $\mathrm{C}$ \\
& & 30 & 1 & $\mathrm{~T}$ \\
Insertion & 4 & $53-54$ & 1 & $\mathrm{G}$ \\
& & $102-103$ & 3 & $\mathrm{~A}, \mathrm{G}, \mathrm{A}$ \\
\hline
\end{tabular}

a significant increase in the frequency of sperm head abnormalities. Chandra and Khuda-Bukhsh (2004) also encountered an abnormal increase in the incident of chromosome aberrations, abnormal red cell nuclei and sperm morphology induced by azadirachtin in a fish, Oreochromis mossambicus. Recently, Cordeiro et al. (2010) have also detected insecticide repellence, irritability and $100 \%$ mortality of the larvae of Chrysoperla externa and Ceraeochrysa cubana. The experimental data generated so far on the toxicity of nimbecidine/ azadirachtin suggests that this pesticide has a considerable potential to cause irreparable damage to the biochemical, physiological and genetic components of the effected living systems. Therefore, bioinsecticides should not be exempted from risk assessment while preferring them for potential use in agriculture. To our knowledge this is the first report to describe the genotoxic effects of this nimbecidine at the molecular level of DNA, which may be considered as a valuable contribution to the data bank of genotoxicity assessment of pesticides. 
Table 4. Substitutions in ITS2 of nimbecidine treated An. stephensi.

\begin{tabular}{lcccc}
\hline $\begin{array}{l}\text { Type of } \\
\text { substitution }\end{array}$ & $\begin{array}{c}\text { Total number of } \\
\text { substitutions }\end{array}$ & $\begin{array}{c}\text { Type of bases } \\
\text { substituted }\end{array}$ & $\begin{array}{c}\text { Total number of } \\
\text { bases substituted }\end{array}$ & Position of bases in the sequence \\
\hline Transition & 15 & $\mathrm{~A} \rightarrow \mathrm{G}$ & 5 & $8,9,59,297,357$ \\
& $\mathrm{G} \rightarrow \mathrm{A}$ & 1 & 100 \\
& $\mathrm{~T} \rightarrow \mathrm{C}$ & 2 & 4,391 \\
& $\mathrm{C} \rightarrow \mathrm{T}$ & 7 & $37,73,197,347,350,400,415$ \\
\hline Transversion & $\mathrm{A} \rightarrow \mathrm{T}$ & 5 & $19,56,82,99,401$ \\
& $\mathrm{~T} \rightarrow \mathrm{A}$ & 5 & $41,57,61,64,98$ \\
& $\mathrm{~A} \rightarrow \mathrm{C}$ & 4 & $62,68,302,332$ \\
& $\mathrm{C} \rightarrow \mathrm{A}$ & 8 & $7,26,27,83,216,319,394,395$ \\
& $\mathrm{G} \rightarrow \mathrm{T}$ & 4 & $35,40,63,280$ \\
& $\mathrm{~T} \rightarrow \mathrm{G}$ & 1 & 39 \\
& $\mathrm{G} \rightarrow \mathrm{C}$ & 2 & 54,55 \\
& $\mathrm{C} \rightarrow \mathrm{G}$ & 10 & $29,36,274,286,330,334$, \\
& & & $354,355,365,402$ \\
\hline
\end{tabular}

Table 5. Sequence characteristics of ITS1 and 2 of control and nimbecidine treated An. stephensi.

\begin{tabular}{|c|c|c|c|c|c|}
\hline \multirow[t]{2}{*}{ S. No. } & \multirow[t]{2}{*}{ Parameter } & \multicolumn{2}{|c|}{ ITS1 } & \multicolumn{2}{|c|}{ ITS2 } \\
\hline & & Control & Treated & Control & Treated \\
\hline 1 & $\begin{array}{l}\text { Total length of sequence (no. of } \\
\text { bases) }\end{array}$ & 767 & 764 & 416 & 418 \\
\hline 2 & GC content $(\%)$ & 55 & 51 & 55 & 53 \\
\hline 3 & AT content $(\%)$ & 45 & 49 & 45 & 47 \\
\hline 4 & Deletions & - & 16 & - & 2 \\
\hline 5 & Insertions & - & 13 & - & 4 \\
\hline 6. & Transitions & - & 93 & - & 15 \\
\hline 7 & Transversions & - & 140 & - & 39 \\
\hline
\end{tabular}

Along with this, the results of present study also advocate the use of PCR which is an accurate, reliable and highly sensitive technique for detecting pesticides related DNA damage.

\section{ACKNOWLEDGEMENTS}

The authors are thankful to Chairperson, Department of Zoology, Panjab University, Chandigarh for providing the necessary facilities to carry out the present research work under the CAS programme of University Grants Commission, New Delhi, India Ref: F-5-4/2006(SAP-II), 7/12/2006, CAS Phase- I.

\section{REFERENCES}

Akudugu, J., Grade, G. and Bohm, L. (2001). Cytotoxicity of azardirachtin Ain human glioblastoma cell lines. Life Sciences, 68: 1153-1160.

Anon, R. (1992). Neem: A tree for solving global problems. Washington: National Academy Press.

Ausubel, F.M., Brent, R., Kingston, R.E., Moore, D.D., Seidman, J.G., Smith, J.A. and Struhl, K. (1999). Short protocols in molecular biology. New York: John-Wiley and Sons.

Awasthy, K.S. (2001). Genotoxicity of crude leaf extract of neem in male germ cells of mice. Cytobios, 106: 151-164.

Awasthy, K.S., Chaurasia, O.P. and Sinha, S.P. (1995). Genotoxic effects of crude extract of neem (Azadirachta indica) in bone marrow cells of mice. Cytologia, 60: 189-193.
Awasthy, K.S., Chaurasia, O.P. and Sinha, S.P. (1999). Prolonged murine genotoxic effects of crude extracted from neem. Phytother. Res., 11: 81-83.

Chandra, P. and Khuda-Bukhsh, A.R. (2004). Genotoxic effects of cadmium chloride and azadirachtin treated singly and in combination in fish. Ecotoxicol. Environ. Saf., 58: 194-201.

Clements, A.N. (1996). The biology of mosquitoes. London: Chapman and Hall.

Cordeiro, E.M., Corream, A.S., Venzon, M. and Guedes, R.N. (2010). Insecticide survival and behavioral avoidance in the lacewings $\mathrm{C}$ hrysoperla externa and $\mathrm{C}$ eraeochrysa cubana. Chemosphere, 81: 1352-1357.

Finney, D.J. (1971). Probit analysis. Cambridge: Cambridge University Press.

Khan, P.K. and Awasthy, K.S. (2003). Cytogenetic toxicity of neem. Food C hem. Toxicol., 41: 1325-1328.

Klopman, G., Conttreras, R., Reosenkranz, H.S. and Waters, M.D. (1985). Structure-genotoxic activity relationships of pesticides: comparison of the results from several shortterm assays. M utat. Res., 147: 343-356.

Liang, G.M., Chen, W. and Liu, T.X. (2003). Effects of tree neem-based insecticides on diamondback moth (Lepidoptera: Plutellidae). Crop Protect., 22: 333-340.

Rao, T.R. (1984). The Anophelines of India. New Delhi: Malaria Research Centre, Indian Council of Medical Research.

Rojanapo, W. and Tepsuwan, A. (1992). Matagenic and antimutagenic activities of some vegetables (in Thai). Bulletin of the D epartment of M edical Services, 17: 461-469. 
Rosenkranz, H.S. and Klopman, G. (1995). An examination of the potential genotoxic carcinogenicity of a biopesticide derived from the neem tree. Environ. Mol. M utagen., 26: 255-260.

Saber, M., Hejazi, M.J. and Hasan, S.A. (2004). Effects of azadirachtin/ neemazal on different stages and adult life table parameters of Trichogramma cacoeciae (Hymenoptera: Trichogrammatidae). J . E con. E ntomol., 97: 905-910.

Sambrook, J., Fritsch, E.F. and Maniatis, T. (1989). Molecular Cloning: A laboratory manual. New York: Spring Harbor laboratory press.

Shoaib, M.A., Mahmoud, M.F., Loutfy, N., Tawfic, M.A. and Barta, M. (2010). Effect of botanical insecticide Nimbecidine on food consumption and egg hatchability of the terrestrial snail M onacha obstructa. J. Pest Sci., 83: 27-32.

Sies, H. (1993). Strategies of antioxidant defense. Eur. J. Biochem., 215: 213-219.

Singh, K.R.P, Patterson, R.S., La-Brecque, G.C. and Razdan, R.K. (1975). Mass rearing of Culex pipiens fatigans Weid. l. Com. Dis., 7: 31-53.
Singh, R.N., Karnan, P., Kulshrestha, V. and Sinha, S.S. (1993) Neem to control pests of tasar. Indian Silk, 32: 42-44.

Sinha, K.C., Riar, S.S., Timmary, R.C., Dhawan, A.K., Bardhan, J., Thomas, P., Khan, A.K. and Jain, R.K. (1984). Neem oil as marginal contraceptive. Indian J. Med. Res., 79: 131136.

Srivastava, M.K. and Raizada, R.B. (2007). Lack of toxic effect of technical azadirachtin during postnatal development of rats. Food C hem. Toxicol., 45: 465-471.

Upadhyay, S.N. and Talwar, G.P. (1993). Antifertility effects of neem, A. Indica, oil in male rats by single intra-vas administration: An alternate approach to vasectomy. J. Androl., 14: 275-281.

Van Der Nat, M.G., Van Der Sluis, K.T.D. and Labadie, R.P. (1991). Ethnopharmocognostical survey of A. indica Juss (Meliaceae). J . Ethnopharm., 35: 1-24.

Williams, J.G.K., Kubeklik, A.R., Livak, K.J., Rafalski, J.A. and Tinge, S.V. (1990). DNA polymorphisms amplified by arbitrary primers are useful genetic markers. Nucleic Acids Res., 18: 6531-6535. 